\title{
MEMOTRET FENOMENA PERAN DAN SIKAPDIVISI KEPATUHAN BANK SYARIAH DALAM PEMBIAYAAN MUDHARABAH
}

\author{
Sirajudin \\ Pascasarjana FEB Universitas Brawijaya Malang dan Dosen Politeknik Negeri \\ Banjarmasin;Jl. Mayjen Haryono 165 Malang; Telp 085754035 908; \\ e-mail:sirajudin@akuntansipoliban.ac.id
}

\section{ABSTRACT}

This research had tried to capture the phenomena of compliance division's role in mudharabah financing of BSX and to disclose the existence and the reason of conventional attitudes' presence among it's role. This research is a qualitative one that using trancedental phenomenology of Husserl to capture the compliance division's role and the conventional attitudes that present in mudharabah financing of BSX. It also has analyzed the reasons of conventional attitude's presence. The result had disclosed the steps in mudharabah financing that involved and entailed SPK as compliance division, they're approval step, melting step, and the step of partial payment on mudharabah financing debt. Based on the phenomena of SPK's involvement, it's found some pictures of SPK's role as watchdog, machine and the commentator. Beside those roles, it's also found conventional attitudes such as vigilance attitude that transformed to skeptical attitude, apathy attitude, and distrusty attitude. The presence of those attitudes during the mudharabah financing process (especailly the involvement of SPK) could not be remove from the "over" preventive attitude of BSX it self, and it seemed as a legitimation of BI for being the sole regulator of Indonesian banking that implanted those attitude in SPK's role.

Keywords: phenomenology, role, conventional attitudes, mudharabah financing, legitimation.

\footnotetext{
ABSTRAK

Penelitian ini berupaya memotret sebuah fenomena peran divisi kepatuhan dalam pembiayaan mudharabah Bank Syariah " $\mathrm{X}$ " dan mengungkap adanya sikap-sikap konvensional yang menyertai peran divisi kepatuhan tersebut. Jenis penelitian ini adalah kualitatif dengan pendekatan fenomenologi transedental Husserl untuk memotret peran divisi kepatuhan dan sikap-sikap yang hadir dalam pembiayaan mudharabah BSX dan menganalisis penyebab hadirnya sikap-sikap konvensional tersebut. Hasil penelitian ini juga mengungkapkan tahapan-tahapan yang sering diikuti dan meniscayakan keterlibatan SPK sebagai divisi kepatuhan BSX dalam proses pembiayaan mudharabahnya. Tahapan-tahapan yang sering diikutinya
} 
antara lain adalah tahapan persetujuan, tahapan pencairan dan tahapan pembayaran angsuran pembiayaan. Berdasarkan fenomena keterlibatan SPK tersebut, ditemukanlah beberapa potret peran SPK dalam proses pembiayaan mudharabah antara lain sebagai watchdog, mesin dan sang komentator. Temuan selanjutnya adalah sikap-sikap konvensional yang hadir dalam peran-peran SPK tersebut. Sikap-sikap konvensional tersebut adalah sikap kewaspadaan yang bertransformasi menjadi sikap kecurigaan, sikap ketidakpedulian, dan sikap ketidakpercayaan. Hadirnya sikap-sikap tersebut tidak lepas dari adanya sikap preventif "yang berlebihan" oleh internal BSX itu sendiri, selain adanya legitimasi dari BI sebagai regulator tunggal perbankan yang ada di Indonesia yang mencangkokkan sikap-sikap ke dalam peran SPK.

Kata kunci: fenomenologi, peran, sikap-sikap konvensional, pembiayaan mudharabah, legitimasi.

\section{PENDAHULUAN}

Perkembangan dunia akuntansi dewasa ini mulai marak dan sebagai bagian dari pengetahuan sosial, akuntansi dalam perkembangannya tidak lepas dengan realita masyarakat yang melingkupinya, sehingga ia tidak bisa hanya terbatas pada hal-hal teknis yang sudah dibakukan oleh sebuah standard setting. Di sinilah akuntansi yang merupakan sebuah produk peradaban manusia pasti merefleksikan kondisi sebuah lingkungan yang membentuknya. Inilah yang disebut dengan value laden, ketika akuntansi tidak lagi bebas nilai, namun sarat nilai yang akan membawa karakter akuntansi menjadi kapitalis, sekuler dan egois (Mulawarman, 2006: 8).

Munculnya gerakan Islamisasi pengetahuan di era 90an, sebenarnya ingin mengcounter maraknya fenomena sekularistik dari pengetahuan (termasuk prakteknya) yang secara masif dilakoni masyarakat muslim. Salah satunya adalah praktek yang ada di perbankan syariah sebagai lembaga atau organisasi yang membawa label Islam (syariah). Bank Indonesia selaku regulator tunggal perbankan yang ada di Indonesia melihat tingkat kompleksitas kegiatan usaha/bisnisperbankanyang memerlukan memitigasi risikokegiatan usaha mereka. Hal tersebut dilakukan dengan peningkatan peran dan fungsi kepatuhanserta satuan kerja kepatuhan yang ada pada bank syariah (PBI No 13/2/PBI/2011). Peningkatan peran yang dimaksud pada peraturan tersebut terkait dengan 
penyesuaian terhadap ketentuan mengenai wajibnya Direksi membentuk Direktur Kepatuhan (Compliance Director) yang membawahi fungsi kepatuhan dan satuan kerja kepatuhan yang diharapkan mewujudkan budaya kepatuhan dalam kegiatan bank. Budaya kepatuhan yang diinginkan adalah dengan menciptakan serangkaian sikap dan tindakanatau langkah-langkah yangbersifat ex-ante (preventif) untuk memastikan bahwa kebijakan, ketentuan,sistem, dan prosedur, serta kegiatan usaha yang dilakukan oleh Bank Syariah.

Sehubungan dengan adanya fungsi kepatuhan di perbankan syariah, dibentuklah satuan kerja kepatuhan yang harus independen dalam sebuah divisi kepatuhan yang di dalamnya terhimpun staf pengawas kepatuhan. Salah satu tugas yang diemban mereka (divisi kepatuhan) pada bank syariah adalah menilai dan mengevaluasi efektivitas, kecukupan, dan kesesuaian kebijakan,ketentuan, sistem maupun prosedur yang dimiliki dengan operasional bank syariah tersebut, termasuk dalam proses pembiayaan mudharabahnya.

Indonesia dengan jumlah penduduknya yang beragama Islam masih banyak yang memiliki kecenderungan bertransaksi/muamalah dengan perbankan konvensional, padahal dalam ajaran Islam dengan tegas dilarangnya aktivitas ribawi. Selain itu, di tengah masyarakat sudah ada rumor tentang masih tidak adanya perbedaan antara praktek di perbankan syariah dengan perbankan konvensional. Melihat kondisi tersebut dan adanya peraturan BI No 13/2 Tahun 2011 yang bertujuan mengatur pengawasan yang ekstra terhadap kegiatan perbankan (termasuk bank syariah) melalui optimalisasi peran fungsi kepatuhan dengan pembentukan divisi kepatuhan serta satuan kerja kepatuhan, maka penelitian ini berusaha memotret "bagaimana peran divisi kepatuhan yang ada dalam pembiayaan mudharabah bank syariah, dan sikap-sikap apa saja yang hadir dalam perannya tersebut?"

\section{TINJAUAN PUSTAKA}

Maraknya perkembangan dunia bisnis termasuk perbankan dewasa ini menutut adanya perhatian yang serius terkait pengawasan dan pengendalian internal dalam sebuah entitas yang dijadikan sebagai sebuah tatakelola perusahaan 
(corporate governance). Salah satu peran penting (diantara banyak peran penting lainnya) dalam tatakelola tersebut adalah kehadiran internal control (pengawasan intern) dengan peranannya sebagai alat membantu manajemen dalam menilai operasiperusahaan dalam mencapai tujuan usaha. Dengan merujuk pada AICPA (American Institute of Certified Public Accountants) tahun 1973, Nasution (2003) menjabarkaninternal control sebagai berikut :

Internal control comprises the plan of organization and all of the coordinated methods and measures adopted within a business to safeguad its assets,check the accuracy and realibility of its accounting data,promate operational efficiency, and encourage adherence to prescribed managerial policies.

Pengawasan intern tersebut meliputi susunan organisasi dan semua metode serta ketentuan yang terkoordinir dan dianut dalam perusahaan untuk melindungiharta benda miliknya, memeriksa kecermatan dan seberapa jauh dataakuntansi dapat dipercaya, meningkatkan efisiensi usaha dan mendorong ditaatinyakebijaksanaan perusahaan yang telah digariskan. Secara singkat pengawasan intern mencakup pengawasan yang dapat dibedakan atas: a) pengawasan akuntansi yang meliputi rencana organisasi dan semua cara dari proseduryang terutama menyangkut dan berhubungan langsung dengan pengamanan harta benda dan dapat dipercayainya catatan keuangan (pembukuan). Pengawasan ini meliputi sistem pemberian wewenang (otorisasi) dan sistem persetujuan serta pemisahan antara tugas operasional, tugas penyimpanan harta kekayaan dan tugas pembukuan, pengawasan fisik dan pemeriksaan intern(internal audit). b) pengawasan administratif yang meliputi rencana organisasi berikut semua cara dan prosedur yang menyangkut efisiensi usaha dan ketaatan terhadap kebijaksanaan pimpinan perusahaan pada umumnya yang tidak langsung berhubungan dengan pembukuan (akuntansi), seperti analisis statistik, time and motion study, laporan kegiatan, programlatihan pegawai dan pengawasanmutu (Hadibroto dan Witarsa, 1984: 6).

Bank Indonesia selaku regulator tunggal perbankan yang ada di Indonesia melihat tingkat kompleksitas kegiatan usaha/bisnisperbankanbegitu masive dan semakin maraknya perkembangan teknologi informasi, globalisasi,dan integrasi 
pasar keuangan. Hal tersebut membuat perlunya upaya-upaya untuk memitigasi risikokegiatan usaha mereka baik yang bersifat preventif maupunkuratif. Upaya tersebut mereka tempuh denganmematuhi berbagai kaidah perbankan yang berlaku untukmengurangi atau memperkecil risiko kegiatan usaha bank dengan peningkatan peran dan fungsi kepatuhanserta satuan kerja kepatuhan yang ada pada bank syariah sehinggapotensi risiko kegiatan usaha bank dapat diantisipasi lebih dini (PBI No 13/2/PBI/2011). Peningkatan peran yang dimaksud pada peraturan tersebut terkait dengan penyesuaian terhadap ketentuan mengenai wajibnya Direksi membentuk Direktur Kepatuhan (Compliance Director) yang membawahi fungsi kepatuhan dan satuan kerja kepatuhan yang diharapkan mewujudkan budaya kepatuhan dalam kegiatan bank.

Budaya kepatuhan tersebut merupakan sekumpulan nilai, sikap, perilaku, dan tindakan yang mendukungterciptanya kepatuhan terhadap ketentuan Bank Indonesia dan peraturanperundang-undangan yang berlaku, termasuk Prinsip Syariah bagi Bank UmumSyariah dan Unit Usaha Syariah. Pada perbankan syariah, adanya sekumpulan nilai yang dilaksanakan di dalamnya merupakan sebuah panduan yang dipakai untuk bertindak atau bersikap, yang biasanya berasal dari dalam diri. Ia bisa berupa prinsip-prinsip bagaimana menjalani hidup dan mengambil keputusan terkait juga dengan pandangan, anggapan, atau kepercayaan mengenaisesuatu itu baik atau buruk untuk dilakukan. Bank syariah sebagai sebuah lembaga atau organisasi yang membawa label Islam (syariah), merupakan sesuatu yang lumrah apabila di dalam aktivitas yang dijalankan mereka terdapat sikap yang kental dengan nilai-nilai Islam. Pada pembiayaan mudharabah misalnya, terjadinya penyerahan modal secara utuh kepada pihak yang lain sebagai pengelola, merupakan sebuah sikap yang mencerminkan nilainilai dan prinsip-prinsip yang melatarbelakangi terlahirnya sikap tersebut.

Sehubungan dengan sikap dan perbuatan manusia, kehadiran fungsi kepatuhan dalam perbankan syariah ditujukan menjadi katalisator budaya kepatuhan. Budaya kepatuhan yang diinginkan seperti terciptanya serangkaian sikap dan tindakanatau langkah-langkah yangbersifat ex-ante (preventif) untuk memastikan bahwa kebijakan, ketentuan,sistem, dan prosedur, serta kegiatan 
usaha yang dilakukan oleh Bank Syariah telah sesuaidengan ketentuan Bank Indonesia dan peraturan perundang-undangan yangberlaku. Tugas dan tanggungjawab dari fungsi kepatuhan adalah memastikan bahwa seluruh kebijakan, ketentuan, sistem, dan prosedur, sertakegiatan usaha yang dilakukan Bank telah sesuai dengan ketentuan BankIndonesia dan peraturan perundangundangan yang berlaku, termasukPrinsip Syariah bagi Bank Umum Syariah dan Unit Usaha Syariah serta meminimalkan risiko kepatuhan bank. Untuk mencapai tugas tersebut dibentuklah satuan kerja kepatuhan yang harus independen dalam sebuah divisi kepatuhan yang di dalamnya terhimpun staf pengawas kepatuhan. Divisi kepatuhan pada bank syariah mempunyai tugas menilai dan mengevaluasi efektivitas, kecukupan, dan kesesuaian kebijakan,ketentuan, sistem maupun prosedur yang dimiliki dengan operasional bank syariah tersebut, termasuk dalam proses pembiayaan mudharabahnya.

Penelitian-penelitian terdahulu terhadap kegiatan di perbankan syariah telah menggambarkan masih dominannya (melekatnya) aura/atmosfer konvensional di dalamnya yang dicerminkan dari sikap, tindakan maupun nilai-nilai yang nampak dalam praktik perbankan syariah (Rosalina, 2004: Jusuf, 2005; Prasetyo, 2008; dan Amira, 2009). Mereka menyimpulkan bahwa masih ditemukannya beberapa prosedur sistem pengendalian internal pada Bank Syariahyang menganut sistem induk bank konvensional. Putriandini (2011) juga mengungkapkan adanya penyatuan nilai-nilai konvensional dan nilai-nilai syariah dalam tahapan proses pembiayaan Musyarakah pada Bank Syariah yang disebabkan adanya keinginan bank untukmencapai laba maksimal (profit oriented). Kasim dkk (2009) menemukan proses audit yang dilakukan pada institusi keuangan syariah yang dari sudut pandang theoritical framework ternyata tidak memiliki perbedaan dengan audit secara umum (konvensional). Hal tersebut dilihat dari lingkup pemeriksaan yang hanya menekankan aspek finansial saja dan adanya kualifikasi personil yang rendah atau kurang mumpuni dan memahami ketaatan operasional lembaga keuangan syariah dengan kaidah dan nilai-nilai Islam. Dwiyana (2011) mengungkapkan beberapa alasan yang melatar belakangi bank memilih prinsip 
revenue sharing yang mencerminkan sebuah makna yang lebih condong mengarah pada kaidah komersial yang dijadikan pertimbangan mereka.

Berkaca pada penelitian tersebut, di mana sebagian dari temuan mengindikasikan masih adanya aura konvensional dalam praktik perbankan syariah yang diindikasikan dari pertimbangan, nilai, dan sikap yang masih konvensional. Fenomena tersebut mengungkap masih adanya sikap-sikap konvensional yang mengikuti dalam aktivitas operasional perbankan syariah.

\section{METODOLOGI PENELITIAN}

Penelitian kualitatif merupakan penelitian yang dilakukan dalam setting tertentu yang ada dalam kehidupan riil (alamiah) yang berbasis pada konsep "going exploring" yang melibatkan in depth and case oriented study atas sejumlah kasus atau kasus tunggal (Finlay, 2006). Metode ini menjadikan data yang bersifat perasaan, norma, keyakinan, kebiasaan, sikap mental dan budaya yang dianut seseorang maupun sekelompok orang dapat ditemukan (Moleong, 2005: 813). Salah satu paradigma yang digunakan dalam penelitian kualitatif adalah interpretif. Paradigma ini dikemukakan oleh Burrell \& Morgan (1994: 227) sebagai paradigma yang meliputi cakupan luas atas gagasan filosofis dan sosiologi yang memberikan karakteristik umum untuk mencoba memahami dan menjelaskan dunia sosial dengan tujuan utama untuk melihat pelaku yang secara langsung terlibat dalam proses sosial.Mahmudi (2003) menjelaskan bahwa pendekatan interpretive social science mengakui adanya kebenaran empirik etik yang memerlukan akal budi untuk melacak kebenaran, menjelaskan fenomena, dan berargumentasi. Paradigma interpretif pada dasarnya dilakukan untuk memahami realitas dunia sosial apa adanya dengan tingkatan pengalaman subyektif (Ludigdo, 2007; 67-68).

Paradigma yang digunakan dalam penelitian ini adalah paradigma interpretif yang tidak digunakan dalam rangka menjelaskan (to explain) dan meramalkan (to predict), melainkan untuk memaknai (to interpret atau to understand) (Triyuwono, 2009; 217).Paradigma ini memandang bahwakebenaran, realitas atau kehidupan nyata tidak memiliki satu sisi, tetapi dapatmemiliki banyak sisi, 
sehingga dapat digali dan dilihat dari beragam sudut pandang.Paradigma ini memotret dunia dan realitanya terdiri atas banyak kebenaran yang saling berhubungan.Untuk itulah perlu disingkap kebenaran-kebenaran tersebut dan hubungannya, dan manusia sebagai pelakunya memiliki kemampuan melalui indera tubuhnya untuk menginterpretasikan atau menafsirkan setiapfenomena yang tertangkap.

Penelitian ini berperspektif interpretif fenomenologi sebagai metodologinya yang berperan sebagai pedoman/petunjuk arah untuk melakukan beberapa cara sehingga mendapatkan pemahaman atau penjelasan yang diharapkan bisa mengungkap akan sebuah fenomena tertentu. Tipe fenomenologi oleh Creswell (2007, 59) bisa dikelompokkan ke dalam dua kategori yakni fenomenologi hermeneutik dan fenomenologi empirikal transedental. Penelitian ini menggunakan fenomenologi kedua (transcendental phenomenology)dikarenakan bebasnya dari persepsi yang lain, sehingga semuanya dianggap "fresh" dari nara sumber dan seolah-olah untuk pertama kali diterima (Moustakas, 1994; 34).

Fenomenologi ini berpedoman pada konsep Husserl, yakni epoche(bracketing) yang membutuhkan eliminasi atas dugaan atau prasangka dan pengetahuan terdahulu oleh peneliti. Dalam fenomenologi transendental, ditegaskan penekanan atas keberadaan realitas sebagai "objek". Penting bagi peneliti menghadirkan kesadaran aktif dalam menangkap dan merekonstruksi suatu gejala dalam rangka mencari makna dan hakikat dari penampakan, dengan intuisi dan refleksi dalam tindakan sadar melalui pengalaman. Hal tersebut pada akhirnya akan dapat membawa kepada ide, konsep, penilaian dan pemahaman yang hakiki (Kuswarno 2009, 46). Sederhananya, fenomenologi ini merupakan pertemuan antara kejadian dan kesadaran. Alat utama penelitiannya adalah intuisi dan refleksi yangsubyektif atas hasil analisis internasional dari subjek yang dilakukan denganproses epoche dengan menyertakan ekstensi atau proses pemahaman, yaitudengan memperhatikan makna dan hal-hal yang bersifat subyektif dibalik apa yangterlihat. Sanders (1982) menyebutkan beberapa langkah yang harus dilakukan dalam metodefenomenologi antara lain: intentional analysis, epoche, dan eideticreduction. 
Penelitian ini menggunakan pendekatan fenomenologi transedental Husserl yang diextended dengan menekankan pada kesadaran informan akan keberadaan realitas sebagai "objek". Pendekatan ini mencoba untuk melihat fenomena peran yang dimiliki divisi kepatuhan pada bank syariah terkait proses pembiayaan modal mudharabah dengan menggali pemikiran sadar diri objek penelitian (informan).

Teknik pengumpulan data empiris tersebut akan peneliti lakukan melalui: a) wawancara (interview) para informan,b) pengamatan partisipasi (participant observation) dan c) pengumpulan dokumen-dokumen yang terkait, seperti hasil review, skema review/pengawasan, prosedur dan standar yang diacu dalam menjalankan tahapan dalam proses pembiayaan mudharabah pada lembaga keuangan syariah. Adapun untuk sumber non empiris yang akan diambil meliputi kitab suci Al Qur'an, Hadist dan literatur Islam lainnya yang khusus membahas tentang proses pemeriksaan yang pernah dilakukan pada masa kejayaan Islam atau generasi sahabat.

Analisis data dalam penelitian ini akan dilakukan dengan beberapa tahapan berikut, yakni: tahap pertama, peneliti akan melakukan analisis intensional dengan menggabungkan noema dan noesis terkait proses pembiayaan mudharabah yang ada pada bank syariah. Noemanya terkait objek yang dipersepsikan informan seperti prosedur, catatan, formulir dan laporan-laporan yang ada dalam proses pembiayaan mudharabah. Noesisnya merupakan pemahaman subjektif para informan terkait pengalaman akan aktivitas operasional organisasi (khususnya proses pembiayaan mudharabah) dan persepsi masyarakat tentang pembiayaan tersebut.

Tahapan kedua merupakan tahapan epoche oleh peneliti terhadap para informan dengan melakukan penggalian data di lapangan secara personal untuk mendapatkan masalah yang terkait dengan mental individu informan. Dalam tahapan ini akan disajikan fenomena secara utuh dengan menanggalkan pandangan, pengetahuan dan persepsi peneliti terhdapa proses pembiayaan mudharabah dan keterlibatan divisi kepatuhan di dalamnya. Selanjutnya merupakan tahapan eidetic reduction dengan menggunakan intuisi dan refleksitas 
peneliti. Pada tahapan ini akan diuraikan dan diungkapkan realitas yang telah diperoleh pada tahapan epoche untuk menemukan esensi atau intisari dari realitas yang ada peran SPK dalam proses pembiayaan mudharabah. Esensi yang akan coba diungkap dari fenomena utuh peran dan tugas SPK dalam proses pembiayaan mudharabah pada bank syariah. Selanjutnya akan diungkap juga sikap-sikap apa yang melekat pada peran dan tugas SPK tersebut untuk kemudian dicermati (disortir) kemungkinan adanya sikap-sikap konvensionaldalam proses pembiayaan mudharabah pada bank syariah. Melekatnya sikap-sikap konvensional yang hadir dalam peran tersebut akan dianalisis untuk mengetahui apa yang menjadi penyebabnya.

\section{PEMBAHASAN}

Situs penelitian ini adalah divisi kepatuhan kantor cabang BSX (staf pengawas kepatuhan, disingkat SPK) yang ada di Surabaya. Staf divisi ini ditempatkan di kantor cabang sebagai perpanjangan kantor pusat BSX. BSX sendiri merupakan bank yang memadukan idealisme usaha dengan nilai-nilai rohani dalam kegiatan usahanya yang tercermin dalam shared valuenya seperti berkomitmen pada kesempurnaan, teamwork yang saling bersinergi, menjunjung tinggi nilai kemanusiaan dan meluruskan niat mencapai ridha Allah, menaati kode etik profesi dan berpikir serta berperilaku terpuji, serta menjadikan mitra pelanggan yang terpercaya dan menguntungkan dengan proaktif dalam menggali dan mengimplementasikan ide-ide terbaru demi pelayanan ke konsumen.

Dalam menjalankan usahanya, selain menghimpun dana dari masyarakat dengan prinsip-prinsip syariah, BSX juga menyalurkan dana tersebut kepada masyarakat dengan beberapa varian pembiayaan dan salah satunya adalah pembiayaan modal mudharabah atau sering disingkat pembiayaan mudharabah. Pembiayaan mudharabah yang ada di BSX memilki karakter yang sama pada pembiayaan yang umumnya ditawarkan pada bank syariah, yakni penyaluran pembiayaan ke nasabah sebesar $100 \%$ atau full financing. Jika dilihat dari ranking proporsi nominal skema pembiayaan yang BSX berikan selama ini, skema pembiayaan mudharabah merupakan skema pembiayaan yang terbesar 
kedua yang disalurkan BSX setelah skema pembiayaan murabahah. Secara umum, skema pembiayaan yang ada di BSX memililki kemiripan dengan prosedur pembiayaan lainnya pada bank syariah, bahkan bisa jadi juga memiliki kemiripan dengan yang ada di bank konvensional.

\section{Keterlibatan SPK dalam pembiayaan mudharabah}

SPK adalah pegawai bank syariah yang bertanggung jawab akan kepatuhan entitasnya dengan peraturan BI, kebijakan dan prosedur intern bank syariah atau peraturan lainnya yang terkait. Kepatuhan tersebut harus dipastikan dilaksanakan oleh seluruh pegawai bank syariah. SPK dalam hal ini berposisi secara lini di bawah divisi kepatuhan kantor pusat bank syariah untuk menjalankan fungsi kepatuhan bank. Secara sederhana, divisi kepatuhan pada bank syariah harus menguji kepatuhan bank syariah dengan regulasi dari BI dan menguji kepatuhan bank syariah dengan semua prinsip-prinsip syariah dalam operasional perbankannya. Divisi kepatuhan erat kaitannya dengan divisi manajemen risiko sehingga acap kali laporan yang dimiliki divisi ini juga diminta atau digunakan sebagai analisis atau evaluasi di divisi manajemen risiko. Ini terlihat dari pernyataan Yazid staf pengawas kepatuhan BSX yang merupakan bawahan langsung dari divisi kepatuhan BSX berikut;

"Tugas kita lumayan banyak Mas. Kan tiap bulan kita bikin laporan yang kita kirim ke kantor pusat. Nah, kadang laporan-laporan kita tersebut juga mereka [divisi kepatuhan] share dengan divisi lain. Yang paling sering ke divisi manajemen risiko"

Divisi kepatuhan yang ada pada BSX mempunyai officer atau staf pengawas kepatuhan (SPK) yang ditugaskan pada kantor pusat dan di kantor wilayah atau kantor cabang. Pada kantor pusat, di setiap direktorat ditempatkan officer pengawas kepatuhan yang akan mengawasi kepatuhan masing-masing divisi dengan kebijakan atau prosedur yang sudah ditetapkan BSX. Demikian juga untuk di kantor wilayah maupun kantor cabang BSX, selalu ditempatkan staf pengawas kepatuhan yang biasanya dipimpin oleh team leader sebagai officer pengawas kepatuhan di tingkat wilayah ataupun di tingkat cabang. Bahkan, terkadang untuk daerah/cabang tertentu hanya ada seorang staf pengawas kepatuhan yang bertanggung jawab sebagai manifestasi dari divisi kepatuhan 
kantor pusat BSX di daerah/cabang tersebut. Secara hierarki susunan/tingkatan penempatan staff pengawas kepatuhan (SPK) yang ada di BSX dapat dilihat pada gambar berikut:

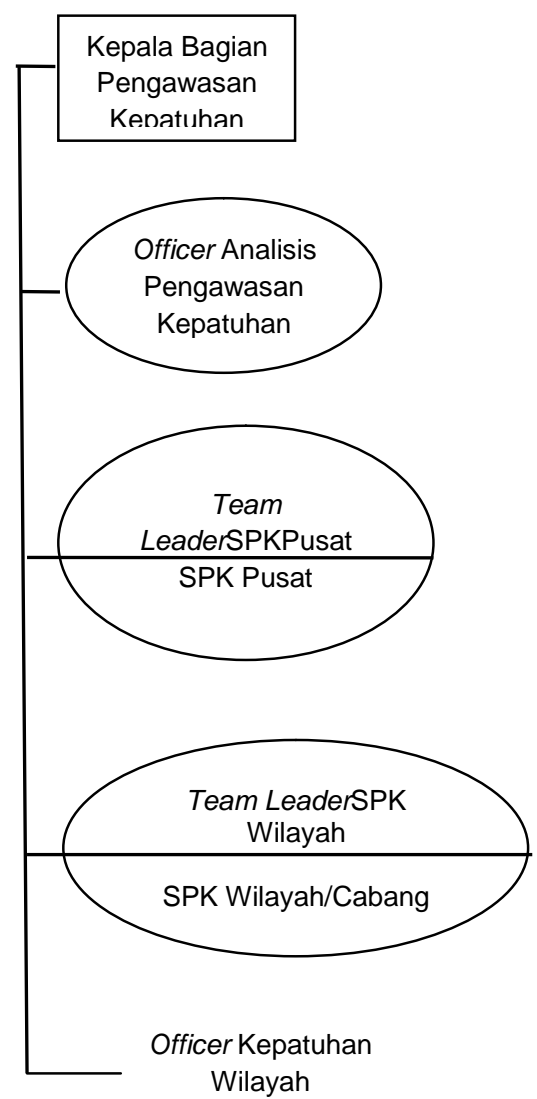

Gambar1 Struktur Organisasi Staf Pengawas Kepatuhan

Berdasarkan surat edaran BSX, SPK yang ada di Cabang/Wilayah secara keseluruhan mempunyai tanggung jawab, antara lain; 1) membuat rencana kerja tahunan yang terkait dengan kegiatan SKP Cabang, 2) memastikan peraturan BI, kebijakan intern, prosedur operasional atau peraturan lainnya telah tersedia di cabangdan telah disosialisasikan, 3) melakukan review sistem dan prosedur operasional cabang mencakup bidang pembiayaan dan non pembiayaan, 4) memastikan ketertiban pengisian checksheet harian compliance procedures dan standar kepatuhan oleh masing-masing petugas/pejabat sesuai dengan tugas dan tanggung jawabnya, 5) melakukan pengawasan untuk menilai tingkat kepatuhan bidang pembiayaan dan bidang operasi (non pembiayaan) berdasarkan 
samplingatau risk based, 6) memastikan kegiatan SDI/Umum telah dilakukan sesuai ketentuan, 7) memastikan telah memadainya keamanan dan kebersihan ruang komputer, 8) melaksanakan pengawasan akuntansi, dan 9) melaksanakan pengawasan bulanan dan tahunan.

Selain hal tersebut di atas, SPK juga melakukan (memastikan) dipatuhinya seperangkat standar/prinsip Islam dalam operasional bank syariah. Ini terlihat dari pernyataan pengawas kepatuhan berikut :

"Iya Mas, kita juga [selaku SPK juga] melakukan pengawasan atau lebih tepatnya kepatuhan bank terhadap ke-syariah-an [mereka] pada penyaluran pembiayaan yang kita berikan. Misalnya, kita memastikan [bank] tidak memberikan pembiayaan terhadap usaha-usaha yang terkait seperti tempat hiburan, perusahaan miras, peternakan babi dan usaha lainnya yang bertentangan dengan ajaran Islam".

Pernyataan tersebut dengan lugas menyebutkan keharusan SPK dalam memastikan apakah pembiayaan (termasuk juga operasional usaha bank) yang disalurkan BSX benar-benar tidak bersentuhan dengan kegiatan atau usaha yang dalam ajaran Islam dilarang. Dari pernyataan tersebut juga tersirat bahwa perbedaan antara pembiayaan pada bank syariah dengan bank konvensional pada umumnya adalah terletak pada keterikatan (perhatian yang besar) bank syariah terhadap kegiatan atau kondisi nasabah atau calon nasabah yang akan mereka berikan fasilitas pembiayaan. Ini memang sedikit berbeda dengan apa yang dilakukan pada bank konvensional dimana mereka tidak begitu memberikan perhatian yang khusus terkait kegiatan usaha nasabah pembiayaannya sepanjang mereka bisa memberikan pengembalian dan keuntungan yang pasti kepada bank.

Secara rinci, SPK BSX mempunyai tanggung jawab utama yang harus ia sampaikan kepada atasannya yakni divisi kepatuhan. Berikut tanggung jawab yang harus dilakukan SPK BSX dalam aktivitasnya; memastikan kepatuhan atas komite pembiayaan, melakukan review atas pembuatan Compliance Self Assessment (CSA) terhadap pembiayaan, memastikan adanya pengawasan dini terhadap aspek kepatuhan pembiayaan \& non pembiayaan, memastikan terpenuhinya penilaian atas Branch Compliance Index (BCI), APU (Anti Pencucian Uang)/PPT (PPTeroris)Index, GCG Index, memastikan telah dilakukannya loan review atas debitur besar secara nasional/cabang, memastikan 
review kolektibitas debitur besar yang masuk daftar NPF dan debitur yang mengalami penurunan kolektibilitas (secara riskbased sampling), dan memenuhi laporan insidentil pengawasan kepatuhan. Untuk masing-masing tanggung jawab tersebut, SPK akan dinilai kinerjanya dengan beberapa indikator seperti Compliance Certificate atas keputusan pembiayaan, Laporan penerbitan CSA/CSAK pembiayaan, Laporan bulanan SPK\&worksheet/checklist, Laporan BCI, APU/PPT Index, GCG Index, Laporan Loan Review, Laporan Review Kolektibilitas, dan Laporan Insidentil.

Secara periodik, dan setiap kali ditemukannya "ketidak-patuhan" baik terhadap prosedur intern maupun peraturan dan kebijakan lainnya yang sudah ditetapkan oleh BSX, maka akan ada warning yang diberikan kepada kantor pusat dan kepada kantor cabang/wilayah (biasanya secara personal terkait posisinya pada kantor yang bersangkutan). Mencermati tanggung jawab yang diemban SPK BSX terlihat bahwa memang penekanan tanggung jawab tersebut masih banyak bersifat konvensional. Artinya titik tekan atau yang jadi indikator dalam pelaksanaan tugas SPK BSX adalah serangkaian laporan-laporan yang pure hanya bersifat keuangan (materi semata). Walaupun mereka juga memastikan usaha/kegiatan bisnis yang dijalankan nasabah atau calon nasabah bank syariah tidak bertentangan dengan kaidah atau muamalah dalam Islam.

Secara umum, tahapan yang sering diikuti SPK dalam proses pengajuan pembiayaan mudharabah adalah pada tahapan persetujuan, tahapan pencairan dan tahapan pembayaran angsuran pembiayaan. Keterlibatan dan bergumulnya SPK dalam proses pembiayaan mudharabah tersebut menghadirkan beberapa potret peran SPK seperti watchdog, mesin, dan sang komentator.

\section{Peran Watchdog}

Peran ini terlahir dari noema (objek yang dipersepsikan dan dijelaskan oleh informan) di mana tugas SPK yang secara rata-rata banyak berkutat dengan aktivitas pengawasan berupa review-review terhadap data (berkas) dan dokumen selama proses pembiayaan berlangsung. Hampir di setiap tahapan proses pembiayaan mudharabah, terdapat review-mereview atas data keuangan dan non keuangan calon nasabah yang dilakukan oleh tim komite pembiayaan. Tim ini 
terdiri dari AO, PMS, MM, dan KC. SPK juga melakukan review lagi data yang sudah diverifikasi/review oleh tim tersebut. Hal ini terlihat dari pernyataan SPK berikut:

"Kalo di kita kan dikumpulkan semua datanya. Notenya apa dan semua kelengkapan data. Semua itu masuknya ke SPK, dari data itu kita mereview."

Pernyataan tersebut mengungkapkan bahwa data yang diajukan calon nasabah setelah direview oleh AO dan PMS nantinya akan dikumpulkan dan disampaikan juga kepada SPK. Berdasarkan data yang ada tersebut, SPK akan membandingkan dengan standar yang harus dijalankan perusahaan (baik terkait aspek risiko dari calon nasabah maupun prosedural yang harus dilakukan oleh staf internal dalam menyaring calon nasabah pembiayaan). Hasil perbandingan tersebut merupakan review yang dilakukan SPK sebagai pengawas kepatuhan untuk memastikan ditaatinya peraturan atau kebijakan internal BSX yang sudah inherent dalam sistem operasional mereka.

Hal penting yang sangat dicermati SPK dalam menjalankan tugasnya adalah sudah atau belum dipenuhinya secara administratif atau aturan BSX oleh calon nasabah pembiayaan mudharabah. SPK juga mencermati apakah prosedur yang dilakukan komite pembiayaan sudah berjalan sesuai dengan indikator atau aturan yang dikeluarkan oleh BSX (kebijakan akan risiko pembiayaan). Pengawasan SPK tersebut di atas biasanya ada di tahapan setelah persetujuan dan sebelum pencairan pembiayaan mudharabah. Ini terungkap dari ujaran SPK berikut:

"Jadi SPK jarang ikut terlibat disetiap tahapan proses pembiayaan"

"Paling tidak sebelum pencairan Mas, artinya di tahapan setelah persetujuan. Persetujuan ini kan komite Mas,... Setelah semua dokumentasi dan persetujuan itu keluar, mereka [semua berkas kelengkapan/data tersebut] harus masuk ke SPK dulu, termasuk persetujuannya, di persetujuannya itu ada saran atau apa lah sekiranya yang menjadi concernnya kepala cabang secara komite"

"Kalo memang itu masih ada yang kurang dari yang commentnya komite itu, SPK berhak melakukan teguran, artinya dalam bentuk memo."

Pernyataan-pernyatan tersebut menyatakan bahwa tidak semua tahapan dalam proses pembiayaan mudharabah diikuti SPK, namun pada tahapan persetujuan dan pencairanlah SPK berjibaku melakukan review terhadap 
kelengkapan berkas administrasi dari calon nasabah (terkait dengan data keuangan calon nasabah) dan juga berkas administrasi dari komite pembiayaan yang berisi pertimbangan komite menyetujui pemberian pembiayaan). Adapun jika setelah dilakukannya review oleh SPK dan terdapat ketidaklengkapan atau ada komentar komite untuk melengkapi berkas yang masuk namun tidak dilengkapi (oleh tim komite - yang terdiri atas KC, MM, LA, dan PMS), maka SPK akan memberikan teguran dalam bentuk memo atau berita acara.

Untuk kasus tertentu, tidak jarang SPK juga memulai keterlibatannya dalam tahapan awal pembiayaan yakni pengajuan pembiayaan, dimana dalam tahapan ini ada kegiatan solisitasi yang berupa melakukan survei langsung ke lapangan (on the spot) terhadap aset/aktiva yang dimiliki calon nasabah. Hal tersebut merupakan noema yang terungkap berdasarkan ujaran berikut:

"SPK sering terlibat disolisitasi bila concernnya pada pembiayaan besar, misalkan 1 M [milyar] ke atas, saya lebih suka ikut. Walaupun itu bukan aturan yang baku, intinya kita menengarai bahwa kalo pembiayaan lebih besar itu risikonya juga lebih besar."

Pernyataan di atas memberikan gambaran bahwa SPK akan selalu mengikuti dan mengawasi dengan cermat tahapan dalam proses pengajuan pembiayaan mudharabah tersebut, pun dalam tahapan awalnya. Pengawasan yang ia lakukan tidak semata kepada calon nasabah, namun juga kepada staf internal BSX yang bertugas melakukan solisitasi tersebut. Sekali lagi, SPK ingin memastikan apakah prosedur operasional BSX dalam proses pembiayaan mudharabah sudah dijalankan dengan benar oleh staf internal BSX. Hal ini dilakukan karena secara tanggungjawab, SPK diharuskan membuat langkah-langkah dan melaksanakan fungsi kepatuhan dalam rangka mendukung terciptanya budaya kepatuhan di seluruh kegiatan bank (berdasarkan piagam kepatuhan BSX).

Noema-noema di atas sebenarnya mengarah pada sebuah noesis (pemahaman subyektif informan) yang berisi experience di dunia perbankan yang selama ini telah menoreh luka atas beberapa kasus yang memberikan kontribusi negatif bagi sektor keuangan. Bahkan merugikan negara (lihat kasus Bank Bali dan Bank Century). Pertimbangan risiko keuangan menjadi sesuatu yang sangat diperhatikan ketika perbankan berinteraksi dengan calon nasabah pembiayaannya. 
Mereka khawatir apabila terjadi kecurangan dalam data yang disampaikan calon nasabah kepada mereka, sehingga review yang mereka lakukan pun berlapis yakni dari staf internal BSX dan SPK selaku pengawas kepatuhan serta tidak menutup kemungkinan auditor internal dan auditor eksternal. Noesis akan hal tersebut ditunjukkan dengan jelas oleh MM dalam pernyataannya berikut:

"Kita tu maunya yang enak-enak, tapi kan kita tidak bisa maunya yang enak-enak terus kan? Kita dalam memberikan pembiayaan harus ada batasan plafond-plafondnya. Dalam arti pemberian tadi itu kita pastikan benar-benar aman..., kemudian apakah ia [calon nasabah] juga punya pembiayaan pada bank lain."

Mereka sebenarnya ingin agar dalam menjalankan usahanya selalu dalam kondisi aman atau tidak terkena risiko yang diistilahkan mereka dengan kata "enak-enak". Sehingga mereka akan memberikan plafond atau batasan-batasan tertentu kepada calon nasabahnya. Dilakukannya pemeriksaan/pengawasan yang ekstra ketat tersebut sebenarnya merupakan kekhawatiran mereka apabila calon nasabah yang mengajukan pembiayaan, ternyata mempunyai historis yang tidak aman dalam masalah penyelesaian pembiayaannya pada bank lain (ini biasanya diperoleh dengan dilakukannya $B I$ checking). Selain itu mereka juga akan membuat mitigasi atau seperangkat prasyarat yang dimintakan kepada nasabah agar pada saat pembiayaan tersebut diberikan, dalam proses pengembalian dan bagi hasil pembiayaan mudharabah tidak mengalami penunggakan. Sehingga tidak aneh apabila mereka melakukan crosscheck dengan database yang ada di BI terkait kemungkinan calon nasabah mempunyai pembiayaan pada bank lainnya beserta historis penyelesaiannya. Penekanannya adalah pihak BSX ingin mendapatkan ke"aman"an ketika ia memberikan pinjaman/pembiayaan kepada calon nasabahnya.

Noesis lainnya terlihat dari pernyataan SPK berikut yang menekankan pada kesesuaian secara aturan maupun administrasi atas kelengkapan data dari calon nasabah yang mengajukan pembiayaan mudharabah.

“...kalo di kita kan dikumpulkan semua datanya, notenya apa dan semua kelengkapan data. Semua itu masuknya ke SPK, dari data itu kita mereview. [Apabila] Valid, ya sudah, baik secara aturan maupun secara adminstratifnya ya sudah, kita akan golkan itu." 
Sekali lagi aktivitas review dilakukan oleh SPK akan data keuangan dan aspek legal lainnya dari calon nasabah. Ia juga berkewajiban memastikan apakah secara prosedural para staf internal BSX yang terlibat sudah menjalankan SOP (aturan) dalam pembiayaan mudharabah. Berdasarkan hal tersebut, yang menjadi “tuan" sang SPK adalah aturan yang dimanifestasikan dengan atasannya di kantor pusat.

Noesis lainnya terkait dilakukannya review atau pengawasan ulang akan aktivitas yang berhubungan dengan pembiayaan mudharabah terlihat dalam tahapan pengembalian angsuran oleh nasabah. Dalam tahapan ini tidak jarang SPK melakukan taksasi lagi walaupun hal tersebut sudah dilakukan oleh PMS atau staf supporting lainnya. Ini terlihat dari pernyataan SPK berikut:

"Kalo [pembiayaan] di bawah itu [5 Milyar] masih boleh ditaksasi oleh cabang sendiri, tapi kan kembali walaupun begitu [taksasinya dari pihak BSX sendiri], masih rentan, artinya, marketing bisa aja main-main di situ, makanya selama ini kepatuhan harus tetap melihat lagi taksasinya marketing."

Dilakukannya pengawasan tersebut semata-mata adanya kekhawatiran dan kewaspadaan yang ekstra akan kemungkinan terlibatnya staf internal dalam membantu nasabah agar pembiayaannya berhasil diberikan. Permainan staf internal tersebut dengan calon nasabah sudah diantisipasi mereka dengan dilakukan multichecking akan data yang diajukan calon nasabah.

Dalam penelitian ini, terdapat noema dan noesis yang diperoleh peneliti melalui epoche terhadap fenomena SPK dalam proses pembiayaan mudharabah pada BSX. Noema yang ditangkap mengungkapkan bahwa SPK selalu melakukan beberapa dan berulang review terhadap data atau note dari tim komite pembiayaan mudharabah. Noesis dari noema tersebut adalah keinginan BSX agar aktivitas usahanya selalu dalam area "aman" dari risiko kegagalan dalam kegiatan usahanya (termasuk pembiayaan mudharabah) dan terhindar dari adanya kecurangan/persekongkolan antara internal bank dengan nasabahnya. Pemerolehan akan noema dan noesis tersebut merupakan analisis intensional terhadap peran SPK dalam proses pembiayaan mudharabah BSX yang akhirnya 
memunculkan peran watchdog ini. Adanya kondisi yang "aman" pada pemberian pembiayaan mudharabahlah penyebab begitu ketatnya (dan berulang/berlapis) pengawasan yang dilakukan SPK dalam tahapan ini. Peran watchdog tersebut peneliti peroleh ketika mencoba memetaforakan kegiatan SPK dalam mereview data calon nasabah dan staf internal BSX sebagai endusan atau gonggongan yang dilakukan anjing pengawas. Tujuan diendus dan digonggongnya nasabah dan staf internal BSX tersebut semata-mata untuk menyampaikan atau memperlihatkan tugas/kinerjanya SPK sebagai watchdog kepada majikannya (dalam hal ini kantor pusat dan regulator perbankan).

\section{Peran Mesin}

Peran SPK diibaratkan laksana mesin, yang peneliti peroleh dari noema SPK pada saat melakukan review atas data calon nasabah pembiayaan mudharabah BSX yang telah dikumpulkan oleh AO dan PMS di tahapan investigasi. Dalam tahapan ini, SPK diibaratkan seperti mesin scanning yang memindai ada tidaknya sesuatu yang tidak sesuai dengan database tertentu, sehingga akan dengan segera diantisipasi atau ditolak sesuatu yang menyertai barang atau benda yang discanning. Hal ini terlihat pada pernyataan yang disampaikan oleh Cahaya sebagai Manajer Marketing yang menyebutkan: “Ketentuan ekstremnya, apabila ia pernah punya pembiayaan macet di bank lain, otomatis[kita] tidak boleh membiayainya", artinya mereka bisa melanjutkan proses pembiayaan tersebut.

Pengecekkan tersebut cukup dengan melihat KTP dan NPWP calon nasabah pembiayaan, kemudian sistem akan memperlihatkan apakah si calon nasabah pernah berhubungan dengan pihak perbankan yang lainnya selain nantinya akan diperlihatkan apakah si calon nasabah mempunyai sejarah terkait data kelancaran kolektibilitasnya.

"Bank Indonesia punya 1 pusat data, jadi minimal dari KTP dan NPWP nasabah itu akan bisa kelihatan, minimal ia sudah pernah berhubungan dengan pihak perbankan mana saja."

"Apabila kemudian setelah kita crosscheck di IDBInya itu [informasi dari BI tentang ia telah berhubungan dengan bank mana saja, berapa jumlah plafondnya berapa jumlah rekeningnya] Bank Indonesia juga ada data kelancaran kolektibiltasnya." 
Informasi tersebut di atas biasanya dicek dan diakses oleh staf internal BSX untuk mensinyalir atau menelisik calon nasabah yang mengajukan pembiayaan. Informasi telah dilakukannya pengecekan oleh tim pembiayaan mudharabah tersebut tertuang dalam SKKP (Surat Keputusan Kelengkapan Pembiayaan). SKKP ini berisi semua ketentuan yang harus dipenuhi calon nasabah pembiayaan baik dari aspek keuangan, legalitas dan aset yang dijaminkan calon nasabah. Untuk aspek keuangan, adanya persyaratan akan dimintanya laporan perkembangan usaha dan terkadang juga diminta batasan minimal atas rasio keuangan tertentu. Apabila ketentuan itu tidak terpenuhi, akan memberikan debit point untuk disetujuinya pemberian pembiayaan.

Point-point yang terdapat dalam SKKP tersebut merupakan hal yang harus diperhatikan oleh staf internal BSX dalam tahapan permohonan pembiayaan mudharabah. Uraian di atas merupakan noema dari proses yang harus dicermati SPK selaku pengawas kepatuhan. Apabila ada salah satu point atau kelengkapan dokumen yang tidak terakomodir atau tidak dipenuhi, maka SPK akan memuatnya pada memo yang akan disampaikan ke KP dan KC (dalam hal ini melalui bagian marketing). Setelah kelengkapan tersebut diuji, maka komite pembiayaan bisa melanjutkan proses tersebut ke tahapan pembuatan SP3 (Surat Persetujuan Pencairan Pembiayaan). Melihat begitu cermat dan telitinya SPK melakukan pengujian terhadap kelengkapan dokumen tersebut di atas, noesisnya adalah adanya opinion risk dari Divisi Assessment Risiko Pembiayaan dan Komersil yang mengikat semua tim komite pembiayaan termasuk SPK untuk melaksanakan pengujian atas sederet kelengkapan dokumen bagi calon nasabah pembiayaan.

Opinion Risk divisi di atas tersebut dibuat berdasarkan pengalaman BSX selama beroperasional terhadap nasabah pembiayaannya. Hal tersebut selalu dilakukan untuk mengantisipasi atau bersifat preventif atas risiko pembiayaan yang mungkin terjadi. Sederhananya, setiap orang tidak mau mengalami risiko kehilangan dananya, dan berusaha melakukan tindakan pencegahan/preventif terhadap risiko tersebut, demikian juga dengan BSX yang menjadi tumpuan nasabah yang menitipkan dananya di BSX. Tindakan preventif tersebut lahir dari 
fenomena bisnis dunia perbankan syariah yang selalu bersentuhan dengan risiko akan bisnisnya. Fenomena tersebut menghasilkan sebuah mantra "high risk, high return". Mantra tersebutlah yang membuat BSX mengantisipasi adanya kemungkinan terjadi risiko kehilangan dananya yang disalurkannya ke masyarakat dengan menerapkan seperangkat aturan dan prosedur yang harus dilengkapi/dipenuhi oleh setiap calon nasabah pembiayaannya, tanpa kecuali bagi calon nasabah pembiayaan mudharabah. Salah satu antisipasi yang disematkan BSX kepada SPK adalah diperankannya SPK sebagai mesin detektor yang akan selalu siap siaga memastikan setiap aturan dan prosedur terkait dengan kelengkapan dokumen dan persyaratan lainnya.

Just such a simply detecting machine. Demikian juga dengan peran dalam tugas yang dijalankan SPK pada proses pembiayaan mudharabah di BSX. Ia hanya menjalankan pemindaian (memastikan kepatuhan) atas semua prosedur dan kriteria dalam proses pembiayaan mudharabah di BSX, dan akan memberikan laporan apabila ada salah satu persyaratan atau prosedur yang tidak dijalankan (dipatuhi) oleh komite pembiayaan laksana alarm pada mesin detector di bandara.

Hal tersebut peneliti dapatkan dari pernyataan SPK berikut:

"Komite pembiayaan itu ada dua ya, komite pembiayaan di cabang dan komite pembiayaan di pusat. Kayak yang seperti tadi aku bilang misalkan [ada] pembiayaan di atas 500 juta, itu otomatis harus ke komite pusat gitu bukan komite cabang"

Digunakannya istilah otomatis oleh informan tersebut mempunyai kedekatan makna dengan istilah dalam dunia mekanik, sehingga nuansa yang hadir pada saat dijelaskannya fenomena pembiayaan mudharabah secara umum oleh Cahaya tersebut menggambarkan betapa atmosfer mesin begitu terasa. Hal tersebut menjadi suatu yang wajar bagi mereka yang bekerja dan bertugas layaknya seperti mesin yang menjalankan setiap prosedur yang menjadi tugasnya.

Indikasi lainnya terkait peran mesin tersebut peneliti temui dalam ujaran berikut:

"Intinya, aspek usahanya, karakternya nasabah, kalo memang ndaworthy ya saya bicaranya ndaworthy, saya mau gimana lagi. Untuk bisa dapat [temuan/fakta] ndaworthy itu ya dapat konfirmasian, input dari entah siapa atau dari mana." 
Ujaran "saya mau gimana lagi" merupakan ungkapan yang menyiratkan bahwa seolah-olah ia tidak bisa apa-apa lagi untuk melakukan tindakan selain yang sudah diberikan/diinstruksikan atasannya. Peran seperti tersebut bersifat mekanikal yang biasa terdapat dalam proses bergeraknya operasional mesin. Artinya tindakan yang dilakoni SPK dalam menjalankan tugasnya sebagai pengawas dalam proses pembiayaan mudharabah di BSX hanya laksana mesin operator. Pernyataan tersebut seolah seperti adanya sesuatu yang terdeteksi oleh mesin detektor di bandara yang hanya memberikan alarm akan terpindainya sesuatu yang "weird" yang harus diwaspadai dan alarm itu juga menandakan bahwa barang tersebut tidak boleh untuk dibawa atau dilanjutkan ke tahapan selanjutnya.

\section{Peran Sang Komentator}

Pernyataan-pernyataan yang sering terlontarkan oleh para komentator pada pertandingan bola pastilah begitu berapi-api alias bersemangat "puool". Bahkan tidak jarang ada komentar yang pedas terkait sikap maupun perilaku pemain di arena pertandingan. Apabila dicermati komentar para komentator tersebut tidak memberikan kontribusi langsung bagi para pemain sepak bola, namun ia sejatinya hanyalah pengantar dan aksesoris fenomena pertandingan kepada pemirsa yang bisa jadi tidak bisa menyaksikan langsung pertandingan tersebut. Seandainya komentar yang dilontarkan tersebut diperhatikan, ia sejatinya hanya akan memberikan (menjadi) masukan untuk pertandingan selanjutnya bukan pada pertandingan yang sedang berlangsung dan dikomentari komentator.

Demikian juga halnya dengan peran SPK yang peneliti peroleh ketika melihat hasil kerja SPK yang berupa memo atau laporan berita acara mereka terkait pelaksanaan tugasnya sebagai pengawas kepatuhan. Sang komentatornya SPK tersebut merupakan sebuah peran SPK yang hanya memberikan warning atau masukan kepada komite pembiayaan, namun tidak mengikat untuk diterima atau dijalankan oleh komite tersebut. Kehadiran peran sang komentator tersebut, peneliti dapatkan dengan melihat noema dan noesis berikut: 
"Pengawas itu nda ada special judgement, ia hanya melaporkan ini lho ada symptomnya seperti ini, indikasinya seperti ini. Untuk penyelidikan investigasi yang lebih mendalam, [dilakukan] mereka [DAI-Divisi Audit Internal]."

Ujaran di atas disampaikan SPK dengan penekanan bahwa tugas mereka ketika menemukan "something" (yang secara aturan atau prosedural merupakan sesuatu yang layak untuk diperhatikan sebagai pertimbangan bagi pengambil keputusan) hanyalah bersifat melaporkan saja. Dalam menjalankan tugasnya, SPK membuat laporan bulanan dan checklist atau worksheetnya terkait pengawasan yang ia lakukan pada kepatuhan pembiayaan dan non pembiayaan. Selain itu tidak jarang SPK juga membuat memo atau berita acara apabila ia menemukan hal yang perlu untuk disampaikan/direkomendasikan diperhatikan staf internal untuk dilakukan. Namun memo yang berisi temuan tersebut tidak bersifat mengikat untuk dijalankan oleh pihak yang menerima memo SPK tadi. Adapun untuk follow up atas temuan SPK tersebut dikembalikan ke pihak yang berwenang. Sebagai contoh dalam kasus tertentu, apabila diperlukan investigasi lebih jauh atas temuan (laporan) SPK tersebut, divisi audit internal lah yang akan menindaklanjuti hasil kerja SPK. Noema tersebut memperlihatkan bahwa SPK hanyalah sebagai penyampai fakta/realita atau pewarta akan aktivitas atau prosedur apa yang terjadi dalam proses operasional BSX termasuk pembiayaan mudharabahnya.

Noema tersebut diperkuat lagi dengan noema berikut yang menyatakan bahwa memo SPK (laporannya) hanyalah bersifat memberitakan kondisi yang diawasi kepatuhannya oleh SPK kepada cabang dan tentunya juga kepada pusat (divisi kepatuhan pusat).

“...hanya kita sebagai PKP harus tetap memberitakan itu. Kita harus warning ke cabang by memo juga."

Secara khusus, tugas SPK dalam proses pembiayaan mudharabah BSX berupa memastikan kepatuhan atas dilakukannya eksekusi atau pemutusan komite pembiayaan. Sebagai indikator pelaksanaan tugasnya tersebut, SPK akan mereview sertifikat kepatuhan (apabila pembiayaan tersebut merupakan limit Kantor Pusat) atau CSA (untuk pembiayaan yang menjadi limit cabang). Sebagai 
bukti telah dijalankannya tugas tersebut, SPK membuat laporan bulanan dan worksheet/checklist atas review yang dilakukannya. Selain itu, setiap SPK menemukan point/prosedur yang tidak dilakukan dan dilewati oleh staf internal (komite pembiayaan, dan yang lainnya), misalnya ada salah satu persyaratan terkait agunan, maka SPK akan mengeluarkanmemo atau berita acara yang berisi temuan SPK atas reviewnya terhadap kelengkapan dokumen yang disebutkan dan dimintakan untuk dilengkapi oleh komite pembiayaan. Memo atau berita acara SPK tersebut sekali lagi tidak bersifat mengikat bagi staf internal untuk diikuti, hal ini bisa saja tidak dilakukan oleh komite pembiayaan dengan memperhatikan pertimbangan komite tersendiri. Sebagai ilustrasi akan ketidakmengikatan memo atau berita acara SPK tersebut terlihat pada pernyataan SPK berikut:

“...karena hasil review saya [SPK] hanya berita acara saja, tidak ada kekuatan untuk merekomendasikan hukuman atau apa pun, cuma itu saja."

"Sifatnya kan berita acara laporan yang dibuat oleh SPK... itu nanti akan tersummarized ke laporan bulanan. Kemudian yang sifatnya itu benar-benar mendasar sekali, kita punya yang namanya laporan insidentiil. Itu khusus satu kasus,...sifatnya berita acara, cuma menerangkan kronologinya."

Pernyataan tersebut menggambarkan sebuah noema bahwa apa yang dilakukan SPK dengan hasil kerjanya hanyalah berupa sesuatu yang tidak mengikat dan tidak memberikan rekomendasi apapun. Ia hanyalah sebuah uraian atau deskripsi akan kronologi sebuah kejadian yang diawasi oleh SPK. Sehingga setiap kali SPK melakukan review atau pengawasan terhadap prosedur di setiap tahapan proses pembiayaan mudharabah, pastinya akan ada berita acara yang dibuat SPK dan terkumpul dalam laporan bulanan yang ia kirimkan ke kantor pusat. Berita acara atau memo yang dibuat SPK tersebut juga disampaikan SPK kepada kepala cabang. Adapun terkait laporan bulanan SPK yang disampaikan ke kantor pusat (tepatnya divisi kepatuhan kantor pusat), hal tersebut semata-mata karena SPK memang merupakan staf kantor pusat yang dititiptugaskan di kantor cabang BSX.

Tergalinya noesis tidak "bertaring"nya memo SPK tersebut dikarenakan secara struktur organisasi, posisi SPK sejatinya berhubungan langsung dengan 
kantor pusat (atasan SPK langsung Divisi Kepatuhan Kantor Pusat) sehingga ia hanya berkordinasi dengan kantor cabang terkait pelaksanaan tugas-tugasnya dalam memastikan kepatuhan operasional kantor cabang BSX. Didesainnya model ketidakmengikatan memo dari SPK bagi staf internal cabang BSX tidak bisa dilepaskan dengan tatakelola perusahaan yang baik bagi sebuah entitas perbankan (menurut BI). Bahkan ada yang menyederhanakan bahwa hal tersebut sengaja didesain agar terjadi pembagian tugas pada divisi atau bagian lain dari BSX. Namun tidak jarang yang hanya mengatakan, "memang sudah seperti itu aturannya, gimana lagi!". Sehingga apa yang mendasari tidak di"reken"nya memo SPK hanyalah perkara yang bersifat regulasi kantor pusat BSX dalam rangka membangun tatakelola perusahaan yang baik. Rujukan tatakelolanya pun masih menginduk pada regulasi BI selaku regulator perbankan di Indonesia yang secara basisnya merupakan regulator perbankan ribawi.

Mencermati noema dan noesis tersebut di atas, peneliti akhirnya memetaforakan peran SPK dengan memonya yang tidak mengikat tersebut seperti peran sang komentator pada sebuah pertandingan sepak bola yang hanya disampaikan untuk mewartakan pemandangan kronologi bagaimana pertandingan berlangsung. Berikut akan diuraikan turunan dari peran sang komentator SPK yang ternyata menghasilkan beberapa sikap dalam pelaksanaan tugas dan tanggungjawab SPK tersebut.

\section{SPK Sebagai Mesin Pengawas dan Komentator}

Penelitian ini berusaha melihat fenomena peran divisi kepatuhan yang ada di perbankan syariah dengan fokus perhatiannya pada proses pembiayaan mudharabah. Dipilihnya proses pembiayaan mudharabah ini berdasarkan pertimbangan bahwa di antara produk perbankan syariah, pembiayaan mudharabahlah yang secara teknis menyediakan $100 \%$ modal untuk dikelola oleh nasabah sebagai mudharib (pengelola dana). Hal ini mengindikasikan adanya tingkat kepercayaan yang tinggi dari pihak bank syariah kepada nasabahnya sehingga disebut dengan terminologi trust financing/investment. (Antonio, 2001: 95). Selain itu, skema pembiayaan ini juga menggambarkan pelaksanaan prinsip 
bagi hasil sebagai basisnya yang sejatinya menggantikan prinsip ribawi yang masih marak dalam aktivitas perbankan di Indonesia. Pemilihan divisi kepatuhan juga tidak luput berkaca pada terminologi "kepatuhan" yang menggambarkan sifat ketundukan atau selalu patuh (taat) mengikuti apa yang menjadi tugas pokoknya.

Peran-peran yang dihadirkan dengan memetaforakan pelaksanaan tugas SPK dalam proses pembiayaan mudharabah ternyataberbuntut dengan kehadiran beberapa sikap yang menyertai masing-masing peran tersebut.

a. Sikap kewaspadaan dan kecurigaan

peran watchdog dalam sebuah organisasi, sejatinya menggambarkan rasa ketidakpercayaan atau kecurigaan atas ketidak-amanan terhadap siapa saja orang yang ada dan masuk ke dalam organisasi tersebut. Ketika mendapatkan penjelasan terkait uraian tugas SPK, ada noema yang tertangkap di dalamnya yakni secara basic, mereka harus mewaspadai setiap orang atau calon nasabah yang mengajukan pembiayaan kepada mereka. Hal ini persis seperti yang dilakukan seekor anjing penjaga malam yang akan menggonggong terhadap siapa saja yang mendekati halaman majikannya, dan tidak jarang mereka akan tetap menggonggong kepada majikannya sendiri.

Sikap kewaspadaan (yang berlebihan) tersebut akan bertransformasi menjadi sikap kecurigaan. Disebut bertransformasinya sikap kewaspadaan ini menjadi kecurigaan dikarenakan adanya pemeriksaan yang ekstra ketat (dan berulang kali) oleh SPK di setiap tahapan pembiayaan. Sikap ini bisa dilacak dari intensitas aktivitas review yang dilakukan SPK setelah tahapan verifikasi pembiayaan mudharabah dilewati.

b. Sikap Kepatuhan

Di balik sikap kewaspadaan yang mengarah pada kecurigaan yang selama ini dijalankan SPK, hadir pula sebuah sikap kepatuhan yang mencerminkan betapa SPK berupaya menjalankan semua prosedur dalam pengawasannya, demikian juga dalam proses pembiayaan mudharabah. Sikap ini terlihat dari dilaksanakannya setiap prosedur terkait dengan pengawasan kepatuhan yang menjadi tanggungjawab SPK. Ini bisa dilacak dari adanya pembuatan laporan 
periodik dan insidentil yang SPK harus sampaikan ke kantor pusat. Hal ini bisa dilihat dari pernyataan berikut:

"SOP untuk SPK ada buku panduannya, tebel. [Panduan] khusus operasional ada, [panduan] khusus pembiayaan juga ada. Intinya kayak audit kebanyakan, ada schedulenya".

Panduan dalam menjalankan prosedur yang dijalankan SPK ternyata dibedakan antara panduan yang berisi manual procedure untuk operasional perbankan dan manual procedure untuk pembiayaan. Hal tersebut mengindikasikan adanya rincian tanggungjawab dan pemisahan perlakuan pengawasan kepatuhan yang harus ditempuh SPK. Dalam panduan tersebut juga terdapat beberapa laporan yang harus dibuat SPK sebagai bukti bahwa ia telah menjalankan prosedur pengawasannya termasuk review atas pencairan dalam pembiayaan mudharabahyang terkumpul dalam laporan bulanan SPK. Selain itu, sikap kepatuhan yang dijalankan SPK juga terlihat ketika ia melakukan screening terhadap kegiatan atau usaha calon nasabahnya yang mereka sebut dengan terminologi syariah compliance.

c. Sikap Ketidakpedulian

Sikap yang hadir selanjutnya adalah adanya sebuah ketidakpedulian dengan dampak dari disampaikannnya temuan SPK selama mengikuti/mereview proses pembiayaan mudharabah BSX. Sikap ini muncul dari tidak bertanduknya warning atau memo yang diberikan atau disampaikan SPK terkait kelengkapan secara dokumen pada tahapan persetujuan pembiayaan. Ini bisa dilihat dari fenomena berikut:

"Setelah semua dokumentasi dan persetujuan itu keluar, mereka [semua berkas kelengkapan/data tersebut] harusnya masuk ke SPK dulu, termasuk persetujuannya, di persetujuannya itu ada saran atau apa lah sekiranya yang menjadi concernnya kepala cabang secara komite, ... itu ada notenya, dan itu harus masuk di SPK. Kalo memang itu masih ada yang kurang dari yang commentnya komite itu, SPK berhak melakukan teguran, artinya dalam bentuk memo. [Memo tersebut] pada prinsipnya 
ke komite tapi menyampaikannya ke marketing. Maksudnya menindaklanjuti kekurangan tersebut."

"Pengawas itu nda ada special judgement, ia hanya melaporkan ini lho ada symptomnya seperti ini, indikasinya seperti ini. Untuk penyelidikan investigasi yang lebih mendalam, [dilakukan] mereka [DAI-Divisi Audit Intern]"

Secara sekilas seolah terlihat adanya penindaklanjutan atas kekurangan yang disebutkan oleh SPK dalam memonya, namun sekali lagi keputusan disetujui atau tidaknya permohonan pembiayaan mudharabah tersebut ada di tangan komite yang terdiri dari MM, KC, AO dan PMS. Artinya warning atau peringatan yang disampaikan SPK dalam bentuk memo tersebut tidak mengikat, dan membuka peluang tetap dijalankannya pembiayaan yang diajukan calon nasabah tersebut ke tahapan selanjutnya oleh komite pembiayaan mudharabah BSX. Warning SPK sebagai pengawas tersebut hanyalah sebatas berita acara sehingga ia bisa saja diacuhkan para petugas atau komite pembiayaan.

Noema tersebut memunculkan sebuah sikap ketidakpedulian pihak lain (baik komite pembiayaan maupun $\mathrm{KC}$ ) dengan memo yang dikeluarkan SPK dalam perannya yang ia sudah jalan dengan totalitas. Walaupun demikian keadaannya, SPK tetap menjalankan perannya karena ia sadar walaupun memonya tidak dipedulikan, secara prosedural ia telah menjalankan apa yang menjadi tanggungjawabnya untuk mengawasi kesesuaian dan kepatuhan proses pembiayaan mudharabah yang ia pantau dengan prosedur yang sudah ditetapkan oleh kantor pusat.

d. Sikap Kejujuran

Sikap kejujuran ini hadir tatkala SPK dengan begitu ketatnya dan polosnya menyampaikan temuan-temuannya dalam mengawasi proses pembiayaan mudharabah BSX kepada pihak-pihak yang secara prosedural harus menerima memo dari SPK. Ini sejalan dengan yang diungkapkan SPK berikut: 
"Atau kondisi yang lain memang nasabahnya itu memang ndaworthygitu, makanya saya sendiri menganalisanya juga nda bagus.

Itu bisa aja dilanggar, dan itu risikonya masih akan tetap di marketing, bukan di manajer operasional"

Sikap kejujuran ini sangat terlihat dalam tahapan persetujuan pembiayaan mudharabah di mana semua anggota komite pembiayaan akan melakukan rapat ringan terkait dengan permohonan pembiayaan dari calon nasabah. Di tahapan inilah kejujuran SPK dalam mereview data yang sudah dikumpulkan PMS dan AO terlihat di mana ia tetap memberikan opini tersendiri berdasarkan analisis yang ia lakukan sendiri (yang tentunya merujuk pada SOPnya selaku bawahan kantor pusat BSX).

e. Sikap Ketidakpercayaan

Ketidakpercayaan dalam proses pembiayaan mudharabah ini ternyata masih ada dan seolah terus dipertahankan demi menjaga organisasi agar tidak mengalami kerugian. Salah satu tugas SPK dalam hal ini adalah memastikan bahwa risiko yang akan diperoleh bank syariah selaku pemberi pembiayaan tidak akan mengalami kegagalan dalam pembiayaannya, baik macet total maupun adanya tingkat kolektibiltas yang tinggi. Selain itu, keterlibatan SPK dalam tahapan proses pembiayaan mudharabah seolah menjadi trigger ketidakpercayaan tersebut kepada calon nasabah dengan dilakukannya review yang ketat dan berulang terhadap informasi dan data keuangan calon nasabah. Sikap ini terlihat dari penjelasan SPK berikut:

“Kalo [pembiayaan] di bawah itu [5 Milyar] masih boleh ditaksasi oleh cabang sendiri, tapi kan kembali walaupun itu [taksasinya dari pihak BSX sendiri] masih rentan, artinya, marketing bisa saja mainmain di situ, makanya kepatuhan [SPK] harus tetap melihat lagi taksasinya marketing."

Pernyataan tersebut menyampaikan sebuah sikap sekaligus nilai ketidakpercayaan dan kecurigaan SPK selaku pengawas kepatuhan dalam bank syariah dengan rekan kerjanya yang ada di kantor cabang. Sikap ketidakpercayaan ini sudah muncul sejak tahapan awal proses pembiayaan 
mudharabah berjalan yakni di tahapan investigasi dan solitisasi kepada calon nasabah. Selain itu, sikap ketidakpercayaan lainnya juga terlihat pada salah satu persyaratan yang dimintakan untuk dipenuhi oleh calaon nasabah pembiayaan mudharabah, yakni terkait adanya jaminan yang dilibatkan dan diikatkan dalam pembiayaan mudharabah.

Walaupun unit analisis penelitian ini adalah organisasi yang (mengklaim) menjalankan kegiatannya berdasarkan prinsip dan nilai-nilai Islam, namun temuan atas penelitian ini menambah lagi temuan yang menyatakan bahwa masih adanya perilaku dan sikap yang tidak Islami (konvensional) dalam industri keuangan syariah (lihat Putriandini; 2011, Dwiyana; 2011, Suprayogi; 2006). Hal mengindikasikan adanya sebuah celah dan kebablasan arah perkembangan perekonomian Islam (yang diwakili industri keuangan syariah) menjadi terbawa arus pragmatisme dunia bisnis. Dari sinilah diperlukannya peran para ilmuwan muslim yang peduli dengan kondisi tersebut untuk menghidupkan kembali aturan Islam sebagai rujukan dalam berekonomi (termasuk akuntansinya), tanpa tercemari godaan pragmatisme kemapanan ekonomi konvensional sekarang.

Secara rutin para SPK BSX yang tersebar di seluruh nusantara melakukan pertemuan rutin di kantor pusat dan terkadang mereka melakukan penyamaan persepsi terkait fungsi mereka dan melakukan refreshment agar kinerja mereka (SPK) tetap asperfect as they can. Hal tersebut seperti proses dilakukannya proses overhaul dalam dunia mekanik agar kinerja mesin tetap dalam kondisi prima. Keprimaan kinerja para SPK tersebut dalam menjalankan tugas dan tanggungjawabnya semakin mengental dan mengkristal ke arah sebuah peran hakiki dari divisi kepatuhan BSX yakni mesin pengawas dan komentator. Bahkan ada pernyataan informal yang disampaikan SPK bahwa pada bulan-bulan tertentu mereka lebih banyak disibukkan dengan training-training atau pelatihan yang berkaitan dengan pemutakhiran kinerja pelaksana kepatuhan. Bahkan tidak jarang mereka (para SPK) setelah dari event rutin tersebut semakin memantapkan mereka menjalankan fungsi pengawasan kepatuhannya pada semua aspek operasional bank syariah termasuk pada pembiayaan mudharabahnya. Berkaca pada agenda- 
agenda besar yang didesain kantor cabang untuk memastikan loyalitas dan segernya kinerja para SPK itulah yang menjadikan SPK benar-benar menjadi mesin pengawas dan komentator hidup yang ada dalam BSX.

Mencermati masing-masing peran SPK seperti yang dijelaskan sebelumnya, secara sederhana bisa dirangkai sebuah peran integral divisi kepatuhan yang ada di BSX, yakni sebuah mesin yang berfungsi sebagai pengawas sekaligus komentator. Peran integral tersebut memiliki makna bahwa SPK layaknya seperti mesin pengawas yang dapat berkomentar dalam menjalankan pengawasan terhadap objeknya. Pengawasan yang dilakukan secara mekanik tersebut merupakan esensi dari peran SPK sebagai wacthdog. Anjing pengawas yang siap setiap saat menggongong terhadap setiap objek yang ada di hadapannya. Uniknya, mesin pengawas ini juga mempunyai kemampuan ekstra yaitu memproduksi suara/komentar atas hasil pengawasannya, sehingga jadilah peran integral SPK sebagai sebuah mesin pengawas dan komentator.

Melihat sikap-sikap yang menyertai pada peran SPK tersebut, secara garis besar bisa dibedakan menjadi 2 sikap utama, yakni sikap konvensional dan sikap yang sesuai dengan aturan syariah (Islam). Sikap konvensional merupakan tindakan-tindakan dan perilaku yang bersifat konsumeristik, individualistik, egoistik dan materialistik yang terkandung dalam suatu perbuatan, dengan fokus orientasinya adalah hal-hal yang bersifat duniawi semata. Adapun sikap syariah berisikan sifat-sifat yang hadir sebagai perwujudan suatu perbuatan yang mengacu/sesuai dengan aturan dan nilai-nilai Islam (Putriandini; 2011, 126).

Dalam pelaksanaan peran SPK ditemukan perpaduan 2 sikap yang berlawanan dan masih mendominasinya sikap konvensional yang hadir atas peran SPK dalam proses pembiayaan mudharabahnya. Sebagai contoh pada peran watchdog, peran ini melahirkan sikap kewaspadaan yang bertransformasi menjadi sikap kecurigaan yang cenderung mencerminkan sikap dengan cita rasa konvensional. Walaupun dalam ajaran Islam diperbolehkannya mempunyai sikap kewaspadaan, namun tidak sampai berlebihan seperti yang ada pada peran watchdog tersebut. Kewaspadaan yang muncul dalam peran ini sudah mengarah pada sikap kecurigaan, sehingga terminologi yang peneliti gunakan terhadap sikap 
yang hadir dalam peran ini adalah kewaspadaan dan kecurigaan. Selain sikap konvensional tersebut, dalam peran ini juga ditemukan sikap lainnya yang secara Islam tidak bertentangan, bahkan sangat dianjurkan yakni sikap kepatuhan. Sikap tersebut sebenarnya masih sering digunakan dan dibutuhkan dalam ranah perbankan konvensional walaupun tentunya masih dengan motivasi materialistik di dalamnya.

Pada peran mesin terdapat perpaduan antar sikap yang ada, namun sikap yang sesuai syariahlah yang sepertinya berusaha mendominasi dengan komposisi dua pertiga dari sikap yang hadir dalam peran tersebut. Sikap-sikap syariah tersebut adalah kepatuhan dan kejujuran. Memotret peran ini ternyata mengantarkan pada sebuah cerminan bagaimana pelaksanaan prinsip-prinsip Islam dijalankan dengan melihat sikap dan perilaku para aktor yang terlibat pada proses pembiayaan mudharabah BSX. Namun sayangnya, hanya ada satu sikap lainnya yang menjadi penetralisir kemurnian sikap-sikap Islami dalam peran mesin ini, yakni adanya sikap ketidakpedulian.

Berbeda dengan peran sang komentator yang peneliti temukan, dalam peran ini boleh dikatakan $100 \%$ cita rasa konvensional sangat kentara, karena semua sikap yang hadir murni sikap-sikap konvensional, yakni ketidakpercayaan dan ketidakpedulian. Sehingga secara keseluruhan, sikap-sikap konvensional selalu ada dalam peran SPK sebagai divisi kepatuhan pada pembiayaan mudharabah BSX.

\section{Melacak Kehadiran Sikap-sikap Konvensional}

Ketidaksengajaan adanya sikap-sikap konvensional tersebut tercermin dari tindakan sadar mereka mengikuti aturan atau regulasi yang dikeluarkan BI. Apabila kita cermati BI sebagai regulator perbankan di Indonesia sejal awal berdirinya memang mempunyai basis ribawi, sehingga paradigma ribawi ini tetap terbawa pada saat ia membuatkan regulasi untuk perbankan syariah. Dari sini lah bisa dipahami bahwa tidaklah aneh dan menjadi wajar apabila sikap-sikap konvensional masih bercokol dan ada dalam praktik perbankan syariah termasuk dalam penelitian ini dengan sorotan divisi kepatuhan pada proses pembiayaan 
mudharabah. Bahkan ada bukti lainnya yang mengungkapkan bahwa produkproduk pada perbankan syariah tidak mempunyai perbedaan yang signifikan dengan produk-produk pada perbankan konvensional. Ini terungkap dari pernyataan informan kunci pada penelitian ini yang mengatakan:

“...alasan praktek-praktek konven itu di syariah masih memungkinkan karena dari produk-produk saja ya kita sebutkan itu sama aja dari produknya syariah dengan konvensional, [misalnya] tabungan, deposito, giro, iya kan? Tapi kalo pembiayaan kita mengikuti aja kan ... itu merupakan pengembangan, artinya lebih kompleksnya di syariah. Lebih bervariasi karena sesuai dengan kondisi nasabahnya, kebutuhan nasabahnya juga."

Entah karena keterbatasan pengetahuan atau ada kesadaran akan fenomena yang sudah begitu terkontaminasinya dengan warna konvensional sehingga pernyataan tersebut keluar dari praktisi divisi kepatuhan BSX. Dari ujaran tersebut diungkapkan bahwa mereka menyadari tidak ada perbedaan antara produk yang ditawarkan bank syariah dengan bank konvensional. Hanya karena adanya pengembangan dari yang biasa dijalankan dalam perbankan konvensionallah yang menjadikan mereka (bank syariah) lebih unik dan kompleks. Selain itu ada lagi pernyataan yang juga menyiratkan bahwa tidak ada perbedaan pratik di bank syariah dan bank konvesional.

"Nda ada bedanya antara bank konven dan bank syariah. Dari produk aja kan sama sebenarnya, kecuali dari akad kita yang beragam. Kemudian nisbah [bagi] bank syariah, [sedangkan] mereka [bank konven] kan menyebutnya bunga."

Ungkapan atau ekspresi yang menyatakan bahwa tidak ada bedanya antara bank konvensional dan bank syariah menjadi sebuah kunci adanya kelemahan dalam menjalankan praktek perbankan syariah yang ada serta kelemahan pemahaman mereka akan muamalah dalam Islam. Bahkan ada ekspresi berani lainnya yang terungkap ketika ditanyakan mengapa dalam praktik pembiayaan mudharabah ditetapkan model pengembalian dana pembiayaan yang bersifat flat (tetap), seperti berikut: 
"Memang $n d a$ boleh bank syariah flat? Ada dalilnya nda? Kalo mau syariah murni, pengusaha berani ndabener-beneropen. Kalo laba mu gede ayo bagiin ke aku."

Pernyataan tersebut sekali lagi memperlihatkan bahwa masih adanya sumber daya insani di perbankan syariah yang belum benar-benar memahami dan menginternalisasikan ajaran Islam serta muamalah Islam dalam sikap mereka. Mereka juga seolah belum memahami bahwa SAK No 105 tentang akuntansi mudharabahparagraf 22 yang mengatur tentang bagaimana pengakuan atas penghasilan usaha mudharabah yang sesuai dengan karakter muamalah Islam. Dalam SAK tersebut pengakuan atas penghasilan usaha mudharabahhanya dapat diketahui berdasarkan laporan bagi hasil atasrealisasi penghasilan usaha dari pengelola dana,bukan dan tidakdiperkenankan mengakui pendapatan dari proyeksi hasil usaha.

Hal tersebut berbeda dengan fenomena yang peneliti temukan di lapangan dimana pengakuan atas hasil usaha mudharabah sudah mereka tentukan berdasarkan proyeksi keuntungan yang akan diperoleh pengelola dana, sehingga nominal angsuran pengembaliannya bersifat tetap (flat). Untuk proyeksi keuntungan pengelola dana pun mereka ambil berdasarkan historis laporan keuangan pengelola dana sebelum difasilitasi pembiayaan mudharabah. Sederhananya, ada prinsip dasar yang tidak dijalankan dalam muamalah ini terkait penentuan keuntungan yang seharusnya fluktuatif berdasarkan realisasi keuntungan atau kerugian yang telah diperoleh pengelola dana nantinya.

Point terpenting dari paragraf itu adalah adanya pengakuan penghasilan dalam usaha mudharabah atau nominal nisbahnya berdasarkan laporan realisasi hasil usaha pengelola dana, bukan berdasarkan proyeksi hasil usaha yang akan pengelola jalani. Selain itu ada juga beberapa pernyataan yang mengindikasikan masih blurrednya pemahaman mereka terkait muamalah dalam perbankan syariah. Atau bisa jadi adanya Islamisasi praktik perbankan konvensional dalam rangka menarik pangsa pasar kaum muslim yang jumlahnya tidak bisa dianggap kecil (karena secara populasi memang besar). Ini menjadi menarik karena memperlihatkan adanya sebuah jebakan pragmatisme dalam ekonomi Islam. 
Pernyataan di atas juga merefleksikan masih adanya sikap ketidakjujuran dan ketidakpercayaan kedua belah pihak dalam bermuamalah. Makanya wajar saja pihak perbankan mempunyai sederet persyaratan yang harus dipenuhi dan diawasi wathchdog kepada para pengaju pembiayaan dan juga internal staff untuk memastikan dipatuhinya standar pembiayaan (mudharabah) yang memiliki penekanan akan tingkat risiko yang relatif rendah dan aman. Deretan persyaratan yang disebut sebagai mitigasi dalam pembiayaan di bank syariah yang seolah menjadi sebuah proses mutanisasi kegiatan perbankan syariah karena pengaruh dari kondisi lingkungan bisnis yang pragmatisme dan tidak (dan belum) "tune in" dengan ajaran Islam. Ini mengindikasikan bahwa pengaruh lingkungan yang melingkupi bank syariah (yakni perbankan ribawi) mempunyai pengaruh yang kuat untuk memasukkan (termasukkannya) beberapa sikap dari lingkungan ribawi tersebut. Penelitian ini memperkuat temuan sebelumnya tentang besarnya pengaruh lingkungan dalam perkembangan praktik akuntansi (Hopwood; 1994, 228). Lingkungan merupakan sebuah habitat dimana keberadaan organisme di dalamnya tidak lepas dengan habitat itu sendiri (Chariri, 2010), sehingga keberadaan beberapa sikap konvensional yang hadir dan berpadu dalam praktik bank syariah, tidak lepas karena ia (bank syariah) merupakan organisme yang ada di habitat konvensional (ribawi).

Praktek pengawasan atas kepatuhan pada proses pembiayaan mudharabah BSX yang direpresentasikan oleh SPK sebagai divisi kepatuhan ternyata membawa tradisi sikap konvensional dalam peran yang dijalankannya. Adanya sikap yang berseberangan dengan ajaran Islam ini tidak bisa dihindari keberadaannya selama regulasi yang mengaturnya masih berhaluan konvensional (ribawi). Peran watchdog, mesin dan komentator yang dijalankan SPK sebenarnya hanyalah sebuah wujud kepatuhan SPK akan aturan atau regulasi yang mengatur entitas besar BSX. Memang, SPK berada dalam sebuah organisasi syariah (yang berusaha menjalankan prinsip-prinsip syariah dalam kegiatannya), namun yang harus juga diperhatikan adalah lingkungan besar lainnya di mana BSX berada. 


\section{SIMPULAN}

Penelitian ini dengan pendekatan interpretifnya, mencoba melihat sebuah fenomena yang ada di perbankan syariah yang direpresentasikan dalam kegiatan pembiayaan mudharabah yang melibatkan divisi kepatuhan (SPK). Fenomena tersebut memotret beberapa peran (watchdog, mesin dan komentator) divisi kepatuhan yang lakoni selama ini secara komprehensif dimetaforakan menjadi peran Mesin Pengawas dan Komentator. Peran-peran tersebut membawa beberapa sikap yang ternyata ada beberapanya dilihat dari kacamata Islam, bertentangan dan tidak semestinya dimiliki sebuah organisasi Islam. Kebertentangan sikap-sikap tersebut dengan ajaran Islam disebut dengan sikapsikap konvensional, dan sepertinya sikap ini sudah inherent dalam perbankan. Sekali lagi menyampaikan pesan bahwa kegiatan ekonomi Islam yang sedang dijalankan kaum muslim dewasa ini masih mempunyai serpihan-serpihan yang perlu untuk ditinjau ulang atau diganti dengan sesuatu yang berkesesuaian dengan aturan Islam. Tercerapnya sikap-sikap konvensional yang ada di lembaga atau organisasi keuangan Islam, disebabkan masih adanya regulator yang secara fundamental berhaluan dan berpedoman kepada keyakinan (aqidah) terhadap keunggulan sistem ribawi (konvensional). Sehingga mereka manifestasikan dalam pembuatan aturan-aturan yang memaksa oraganisasi atau institusi yang dinaunginya untuk mengimplemantasikannya.

Sikap-sikap praktisi yang bersifat pragmatis dan bertentangan dengan nilai dan prinsip-prinsip dalam organisasi Islam. SPK yang merupakan aktor yang disoroti dalam penelitian ini, sebagai pengawas kepatuhan organisasi dalam menjalankan kegiatan muamalahnya berdasarkan prinsip-prinsip Islam, ternyata mempunyai perpaduan sikap-sikap Islam dan sikap-sikap konvensional. Penelitian selanjutnya bisa dikembangkan lebih dalam lagi adalah meneliti nilainilai apa yang mendorong lahirnya sikap-sikap konvensional dalam organisasi atau lembaga keuangan Islam ditambah teori institusional sebagai alat analisisnya. 


\section{DAFTAR PUSTAKA}

Amira. 2009. Evaluasi Sistem Pengendalian Intern Pembiayaan Musyarakahpada PT. BPRS Bhakti Haji Malang, Skripsi, Universitas Muhammadiyah,Malang.

Antonio, Muhammad Syafi'i. 2001. Bank Syariah: Dari Teori Ke Praktik. Gema Insani, Jakarta.

Burrell, G. \& G. Morgan. 1994. Sociological Paradigms and Organizational Analysis. Arena

Creswell, John W. 2007. Qualitative Inquiry And Research Design:Choosing Among Five Approaches. Second Edition.Sage Publications, Inc.United State of America.

Dwiyana, Zuhrina F. 2011. Mengungkap Makna di Balik Implementasi Revenue Sharing. Tesis,Universitas Brawijiaya, Malang.

Finlay, L. 2006. Qualitative Research for Allied Health Professionals: Challenging Choices. Edited by Linda Finlay and Claire Ballinger.John Wiley \& Sons Ltd.New York

Hadibroto, H.S. \& Oemar Witarsa. 1984. Sistem Pengawasan Intern (System of Internal Control), Edisi 2, FE Univ. Indonesia, Jakarta

Jusuf, Alisa Haqiqi. 2005. Analisis Faktor-Faktor yang Dipertimbangkan dalamPenentuan Nisbah Bagi Hasil atas Pembiayaan Musyarakah pada BankSyariah, Tesis, Universitas Airlangga, Surabaya.

Kasim, Nawal Bbinti., Shahul Hameed Mohamad Ibrahim dan Maliah Sulaiman. 2009. Shariah Auditing in Islamic Financial Institutions:Exploring the Gap Between the "Desired" and the "Actual". Global Economy \& Finance JournalVol. 2 No. 2 September. Pp. 127-137

Kuswarno, Engkus. 2009. Metodologi Penelitian Komunikasi, Fenomenologi(Konsep, Pedoman, dan Contoh Penelitian). Widya Padjajaran UNPAD,Bandung.

Ludigdo, Unti. 2007. Paradoks Etika Akuntan. Pustaka Pelajar. Yogyakarta.

Mahmudi.2003. Studi Kasus Sebagai Strategi Riset untuk Mengembangkan Akuntansi Sektor Publik.JAAI.Vol. 7 No. 1.Juni. Hal 51-65.

Moleong, Lexy. 2005. Metodologi Penelitian Kualitatif. PT. Remaja Rosdakarya. Bandung 
Moustakas, Clark, E. 1994. Phenomenological Research Methods.Sage Publications, Thousand Oaks California.

Nasution, Manahan. 2003. Sekilas Tentang Internal Auditor. Diunduh dari http://repository.usu.ac.id/bitstream/123456789/1221/1/akuntansimanahan2.pdf per 28 April 2012

Prasetyo, Eko. 2008. Evaluasi Sistem Pengendalian Intern PembiayaanMurabahah pada PT.BTN Kantor Cabang Syariah Malang, Skripsi,Universitas Muhammadiyah, Malang.

Putriandini, Silviana. 2011. Nilai-nilai Konvensional dalam Implementasi Sistem Pengendalian Internal pada Pembiayaan Musyarakah: Sebuah Studi Fenomenologi, Tesis,Universitas Brawijiaya, Malang.

Rosalina, Anita. 2004. Sistem Pengendalian Intern Pembiayaan dalamPenyaluran Pembiayaan Kepada Masyarakat (Studi Kasus pada BankBRI Syariah Malang, Skripsi, Universitas Muhammadiyah, Malang.

Sanders, Patricia. 1982. Phenomenology: A New Way of Viewing OrganizationalResearch. Academy of Management Review.Vol. \& (3) pp. 353-360.

Shahul, H.M.I and Yay, R. 2005. The Objectives and Characteristics of Islamic Accounting: Perceptions of the Malaysian Accountans and Accounting Academics. Malaysian Accounting Review

Suprayogi, Noven. 2006. "Aktivitas Pengawasan Internal Syariah pada BankSyariah (Studi Kasus pada BPRS Bhakti Makmur Indah Sidoarjo)", Tesis,Magister Akuntansi, Universitas Airlangga, Surabaya.

Triyuwono, Iwan. 2000. Organisasi dan Akuntansi Syariah. LKiS. Yogyakarta.

Triyuwono, Iwan. 2009. Perspektif, Metodologi, dan Teori Akuntansi Syariah. Rajawali Pers.Jakarta. 
